University of Nebraska - Lincoln

DigitalCommons@University of Nebraska - Lincoln

Papers in the Earth and Atmospheric Sciences Earth and Atmospheric Sciences, Department
of

2012

\title{
Mapping mean annual groundwater recharge in the Nebraska Sand Hills, USA
}

Jozsef Szilagyi

Budapest University of Technology and Economics, jszilagyi1@unl.edu

Vitaly A. Zlotnik

University of Nebraska-Lincoln, vzlotnik1@unl.edu

John B. Gates

University of Nebraska-Lincoln, jgates2@unl.edu

Janos Jozsa

Budapest University of Technology and Economics

Follow this and additional works at: https://digitalcommons.unl.edu/geosciencefacpub

Szilagyi, Jozsef; Zlotnik, Vitaly A.; Gates, John B.; and Jozsa, Janos, "Mapping mean annual groundwater recharge in the Nebraska Sand Hills, USA" (2012). Papers in the Earth and Atmospheric Sciences. 374. https://digitalcommons.unl.edu/geosciencefacpub/374

This Article is brought to you for free and open access by the Earth and Atmospheric Sciences, Department of at DigitalCommons@University of Nebraska - Lincoln. It has been accepted for inclusion in Papers in the Earth and Atmospheric Sciences by an authorized administrator of DigitalCommons@University of Nebraska - Lincoln. 
Published in Hydrogeology Journal 19:8 (2012), pp. 1503-1513; doi: 10.1007/s10040-011-0769-3

Copyright $@ 2011$ Springer-Verlag. Used by permission.

Submitted February 9, 2011; accepted July 11, 2011; published online July 28, 2011.

Supplementary material is presented following the References.

\title{
Mapping mean annual groundwater recharge in the Nebraska Sand Hills, USA
}

\author{
Jozsef Szilagyi, ${ }^{1}{ }^{2}$ Vitaly A. Zlotnik, ${ }^{3}$ John B. Gates, ${ }^{3}$ and Janos Jozsa ${ }^{1}$ \\ 1. Department of Hydraulic and Water Resources Engineering, Budapest University \\ of Technology and Economics, Muegyetem Rakpart. 3-9, 1111 Budapest, Hungary \\ 2. School of Natural Resources, University of Nebraska-Lincoln, \\ 3310 Holdrege Street HH625, Lincoln, NE 68583, USA \\ 3. Department of Earth and Atmospheric Sciences, University of Nebraska-Lincoln, \\ 214 Bessey Hall, Lincoln, NE 68588-0340, USA \\ Corresponding author - Jozsef Szilagyi, email jszilagyi1@unl.edu
}

\begin{abstract}
Mean annual recharge in the Sand Hills of Nebraska (USA) over the 2000-2009 period was estimated at a 1-km spatial resolution as the difference of mean annual precipitation $(P)$ and evapotranspiration (ET). Monthly $P$ values came from the PRISM dataset, while monthly ET values were derived from linear transformations of the MODIS daytime land-surface temperature values into pixel ET rates with the help of ancillary atmospheric data (air temperature, humidity, and global radiation). The study area receives about $73 \mathrm{~mm}$ of recharge (with an error bound of $\pm 73 \mathrm{~mm}$ ) annually, which is about $14 \pm 14 \%$ of the regional mean annual $P$ value of $533 \mathrm{~mm}$. The largest recharge rates (about $200 \pm 85 \mathrm{~mm}$ or $30 \pm 12 \%$ of $P$ ) occur in the south-eastern part of the Sand Hills due to smoother terrain and more abundant precipitation (around $700 \mathrm{~mm}$ ), while recharge is the smallest (about $40 \pm 59 \mathrm{~mm}$ or $10 \pm 14 \%$ of $P$ ) in the western part, where annual precipitation is only about $420 \mathrm{~mm}$. Typically, lakes, wetlands, wet inter-dunal valleys, rivers, irrigated crops (except in the south-eastern region) and certain parts of afforested areas in the south-central portion of the study area act as discharge areas for groundwater.
\end{abstract}

Keywords: Groundwater recharge/water budget, MODIS data, USA, Remote sensing

\section{Introduction}

With increasing emphasis on integrated management of groundwater and surface-water resources, there is high demand for improvements to regional hydrologic models covering areas on the order of $10^{4} \mathrm{~km}^{2}$ or greater. Among various water cycle characteristics, groundwater recharge is the leading hydrologic parameter determining groundwater resources availability and sustainability. Groundwater recharge is generally not directly measured, but rather inferred from more easily measurable physical and chemical parameters, often with the help of models with varying complexity (Crosbie et al. 2010a, b). Methods of estimating groundwater recharge are broadly categorized as waterbudget methods, modeling methods, physical methods involving saturated and unsaturated zones, and tracer techniques involving chemical, isotopic, and heat tracers (Healy 2010). In spite of the variety of the available techniques, precise recharge estimation is difficult because of high levels of uncertainty associated with most estimation methods (Scanlon et al. 2002).

Determining spatially explicit recharge rates for model cells on the scale of $\sim 1 \mathrm{~km}^{2}$ is a current challenge for improving regional hydrologic models. In most cases, obtaining field-based estimates for each model cell would be prohibitively expensive. As a result, methods which integrate remote sensing for recharge estimation at these scales have generated recent interest (Brunner et al. 2004, 2007). The water-balance approach which formulates recharge as the difference in precipitation $(P)$ as well as the sum of surface/subsurface runoff and evapotranspiration (ET) - averaged over a suitably long period to make changes in storage negligible-is amenable for such applications. ET can typically be inferred from remote sensing while precipitation data are avail- 
able from numerous weather stations. However, limitations on the accuracy of $P$ and ET may lead to significant errors that propagate to recharge rates when the latter is estimated as the difference between $P$ and ET. This is an inherent problem in semi-arid or arid climates when $P$ and ET are of similar magnitude. For example, in the Badain Jaran Desert in China, the difference between $P$ and ET is on the order of $1 \%$ of $P$ (Yang et al. 2010).

Any spatial field of recharge-rate values derived from remote-sensing data is generally considered to be unreliable unless it is compared with field-based estimates that can provide "ground truth" (Brunner et al. 2007). Without field-based verifications, remote-sensing estimates may yield erroneous flux rates even when they contain valid information on spatial patterns and relative spatial distributions. However, the fieldwork required for verification is the most resource-intensive component of the analysis and often unfeasible over large areas (Brunner et al. 2004, 2007). Furthermore, different methods integrate differing areal scales, making direct comparisons between field-based and remotesensing-based estimates a challenge. Nevertheless, it is advantageous to apply multiple methods for estimating recharge where possible because of the large uncertainties associated with current recharge estimation methodologies. Although estimates from multiple methods may not quantitatively reduce uncertainty (Healy 2010), their application may provide insight into hydrological and morphological recharge patterns, measurement errors, and validity of assumptions.

The objectives of this study are to (1) assess the spatial distribution of recharge in the Nebraska Sand Hills (NSH) within the High Plains, USA, at $\sim 1 \mathrm{~km}^{2}$ spatial resolution with the help of a novel ET estimation approach, and; (2) compare the results with alternative techniques available at different spatial scales. The comparison of results with multiple techniques of varying spatial scales is not yet common practice in groundwater recharge studies, and is certainly the first such investigation in the NSH. The comparison of remote-sensing-derived ET rates include (1) baseflow/streamflow analysis, utilizing observed streamflow data at the catchment scale (i.e., at the North Loup, Middle Loup and Dismal River watersheds; 5,823, 4,694, and 5,331 $\mathrm{km}^{2}$, respectively); (2) a groundwater chloride mass-balance approach applied at the subcatchment (plot) scale ( $\left.100 \mathrm{~m}^{2}\right)$, and; (3) calibration of a regional groundwater model (Middle Loup and Dismal River watersheds) using observed water-table elevations and streamflow.

\section{Study area}

The Sand Hills region of Nebraska (Figure 1) is the largest grass-covered sand dune area in the western hemisphere. Due to its permeable soil and considerable saturated thickness -150-250 m (Bleed and Flowerday 1989) - it has long been regarded as one of the most important groundwater-recharge areas for the Ogallala aquifer, a vital source of water for irrigated agriculture in the central US making Nebraska the leading state in irrigated area (8.5 million ha) and irrigation-water consumption. The climate in the NSH is continental, with a mean annual temperature of about $10^{\circ} \mathrm{C}$, and annual precipitation of $533 \mathrm{~mm}$. There is a significant precipitation gradient from east to west across the Sand Hills, the eastern-most part receiving more than $700 \mathrm{~mm}$, while the western-most only about $400 \mathrm{~mm}$, annually (Figure 2). Due to high hydraulic conductivity of the sandy soils (Wang et al. 2009), surface runoff is minimal; therefore, the streams in the NSH are predominantly fed by groundwater baseflow and, thus, maintain a fairly steady flow system throughout the year (Bleed and Flowerday 1989). Szilagyi et al. (2003) estimated that baseflow may exceed $95 \%$ of the total annual flow in certain streams of the NSH, and stays above $90 \%$ overall for the streams of the region.

The Sand Hills, due to its negligible surface runoff, and rolling topography is ideally suited to utilize the vadose-zone water-balance approach for estimating mean annual recharge rates as the difference in $P$ and ET over a suitably chosen spatial resolution and sufficiently long period so that the change in soil moisture becomes negligible in comparison with the cumulative fluxes across the surface. The spatial resolution must be larger than the characteristic horizontal dimension of the sand dunes in order to allow the infiltrated water to reach the saturated zone in the same cell after escaping the root zone of the vegetation.

\section{Methods}

\section{Remote sensing for estimation of ET and groundwater recharge}

Mean annual recharge is estimated as the difference in $P$ and ET rates of individual moderate resolution imaging spectroradiometer (MODIS) cells. MODIS data have been collected for over a decade at a nominal spatial resolution of about $1 \mathrm{~km}^{2}$. Using MODIS daytime surface temperature $\left(T_{s}\right)$ and ancillary climate data, ET at $\sim 1-\mathrm{km}^{2}$ resolution was mapped for Nebraska by Szilagyi et al. (2011). For the mapping the 8-day composite MODIS daytime surface temperature data for 2000-2009 were averaged for each month to obtain one surface temperature per pixel per month. Mean annual precipitation (not required for the ET mapping), mean monthly maximum/minimum air and dew-point temperature values were downloaded from the PRISM database (Prism Climate Group 2004) at 2.5-min spatial resolution. Mean monthly incident global radiation data at half-degree resolution were obtained from the GCIP/ SRB site (NOAA 2009). The ET estimate results from a linear transformation of the monthly mean $T_{\mathrm{s}}$ value of each MODIS cell with the help of the ancillary climate data (for a detailed description of the ET estimation method see Szilagyi et al. 2011).

Because accuracy of the ET values is so critical in the estimation of recharge rates, the original mean annual 


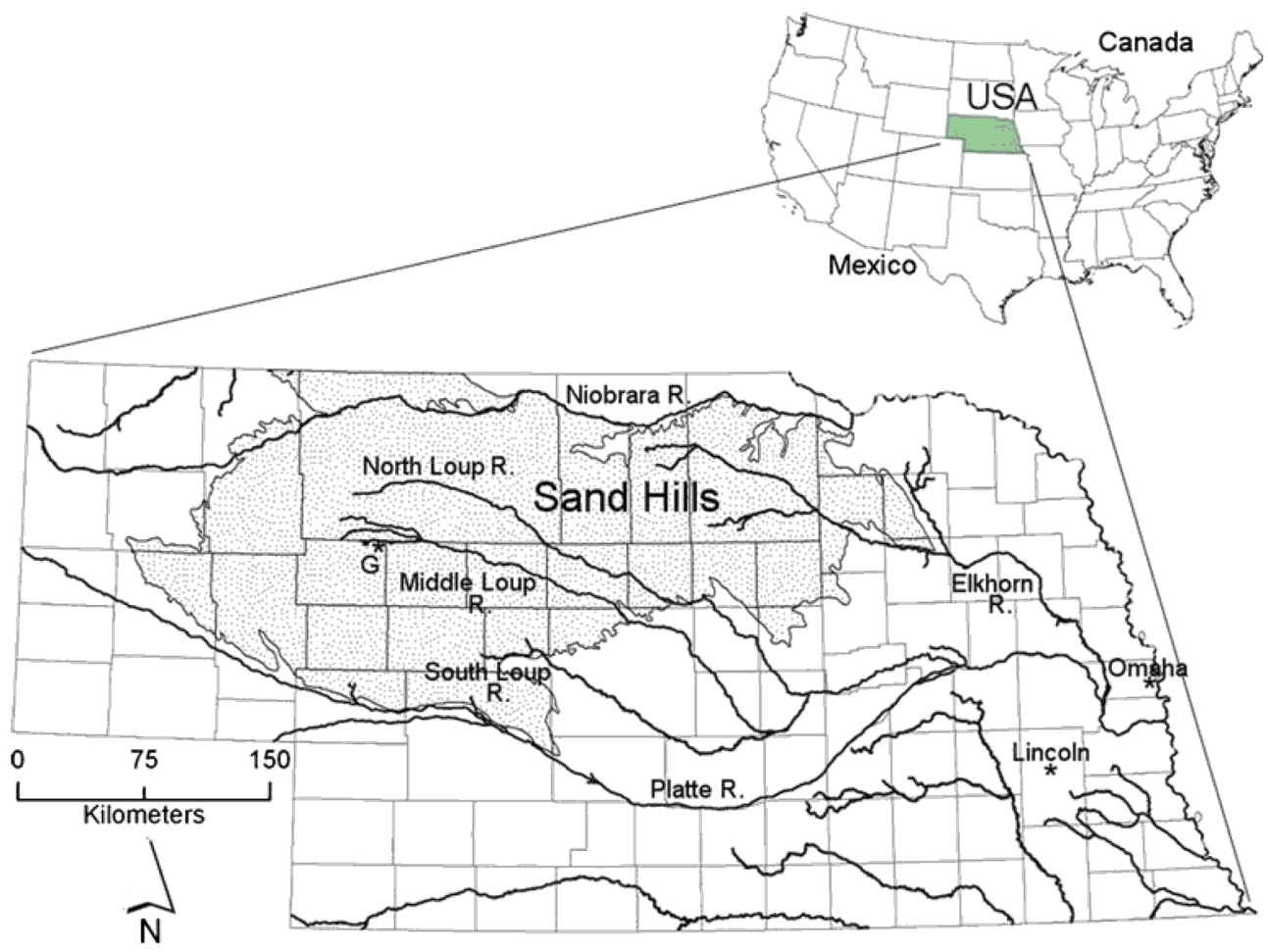

Figure 1. Location of the Sand Hills of Nebraska and the site (G Gudmundsen Ranch) where multiyear field measurements (Energy Balance Bowen-Ratio, EBBR) of evapotranspiration (ET) are available. The thin lines are county boundaries.

ET values for the Sand Hills were corrected by multiyear energy balance Bowen ratio (EBBR) data measured near the center of the Sand Hills, over three differing hydrologic settings: wet meadow, dry meadow, and dune top at the Gudmundsen Research Facility (see Figure 1). Based on comparisons of the corresponding pixel ET rates, Szilagyi et al. (2011) reported a 7.6\% overesti- mation (by the MODIS-based method) of the site-averaged mean annual EBBR values. Figure 3 displays the corrected (the original pixel values multiplied by 0.93 ) map ET values, which were used subsequently for the estimation of the spatially distributed mean annual recharge rates. The precipitation field values of PRISM were accepted as best available estimates.

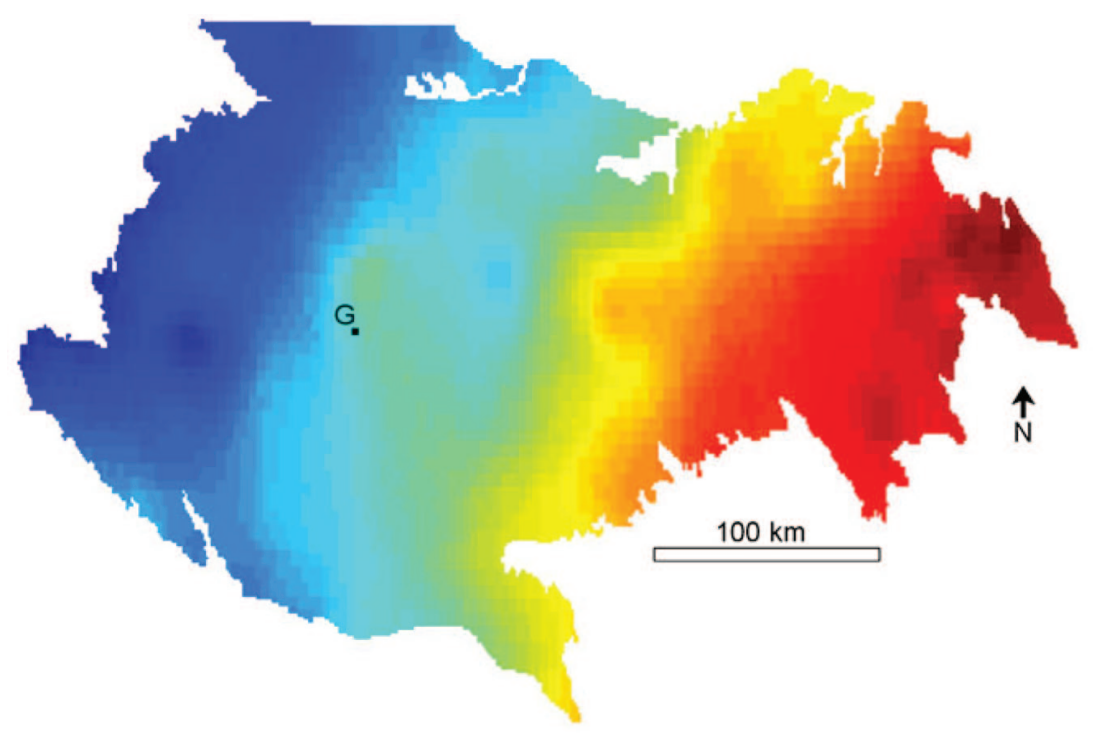

$\mathrm{mm} / \mathrm{yr}$

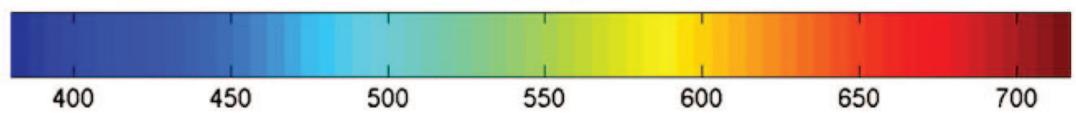

Figure 2. Period averaged (2000-2009) mean annual precipitation $(P)$ rates (mm) in the Sand Hills. 


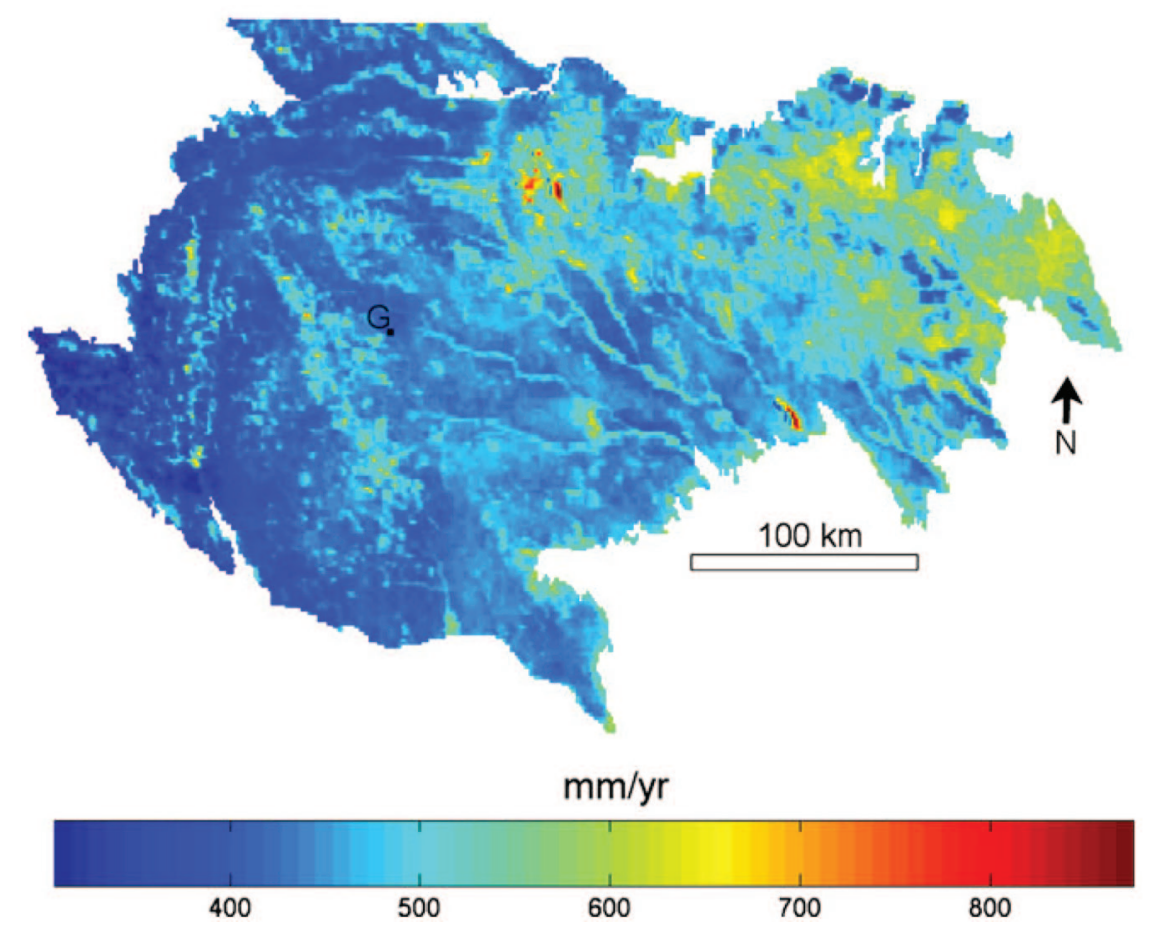

Figure 3. Period averaged (2000-2009) and EBBR-corrected mean annual ET rates (mm) in the Sand Hills.

The present estimation of the mean annual recharge rates necessarily assumes no significant long-term trends in soil moisture. The water-table elevations have not changed significantly at the NSH over the study period (Korus and Burbach 2009) which indirectly supports this assumption.

\section{Chloride mass balance}

A steady-state chloride $(\mathrm{Cl})$ mass-balance recharge estimation was performed for the NSH based on publically available data on groundwater ion concentrations from the National Water Quality Assessment (NAQWA) Program (USGS 2009) and on atmospheric wet deposition from the National Atmospheric Deposition Program (State Agricultural Experimental Stations (2010). Recharge $(R)$ is estimated as $R=P \cdot C_{\mathrm{P}} / C_{\mathrm{R}}$ where $C$ ${ }_{\mathrm{P}}$ is dry deposition-adjusted $\mathrm{Cl}$ concentration in precipitation, and $C_{R}$ is $\mathrm{Cl}$ concentration in the groundwater. The method assumes that $\mathrm{Cl}$ concentrations in groundwater are dominantly affected by atmospheric sources (Gates et al. 2008), which appears to be a reasonable assumption for the NSH because there are no known subsurface sources of chloride to shallow groundwater and there are minimal anthropogenic impacts on groundwater chemistry. Cattle feedlot operations and reflux of saline lake water to shallow groundwater may occur in some areas but related impacts on groundwater $\mathrm{Cl}$ are likely to be limited to the local scale.

By extracting all NAQWA entries for groundwater between 2002 and 2004, a total of 32 different sites within the NSH was obtained. One outlier was discarded from this data set because of abnormally high $\mathrm{Cl}$ concentration $(33 \mathrm{mg} / \mathrm{L})$ in a shallow well sample $(30 \mathrm{~m})$. Wet deposition was estimated using monitoring data from the nearest NADP station (North Platte Agricultural Experiment Station: N 41.0592; W -100.7464; elevation $919 \mathrm{~m}$ above sea level (asl); data period of 19852009; mean $=0.35 \pm 0.11 \mathrm{~kg} / \mathrm{ha}$ ). . Dry deposition data for the NSH are not currently available. The common assumption that the dry deposition rate for $\mathrm{Cl}$ is approximately equal to the wet deposition rate, based on ${ }^{36} \mathrm{Cl} /$ $\mathrm{Cl}$ studies from the southern High Plains (Scanlon and Goldsmith 1997), was applied.

\section{Baseflow/streamflow-based recharge estimation}

Because streamflow in the NSH is predominantly baseflow (therefore the NSH rivers practically never flood), a catchment-representative bulk recharge value can, in theory, be estimated as the ratio of observed mean annual stream discharge and the corresponding groundwater drainage area. The resulting estimates, however, may be laden with relatively large errors (the extent of which is unknown in the NSH) due to uncertainties in the contributing groundwater drainage area value, as discussed in the following.

\section{Results}

\section{Error range of recharge estimates}

The semi-arid climate of a large portion (the western side) of the study area necessarily increases the error range for water-balance recharge estimation. The error range can be obtained by elementary quantitative uncertainty analysis. Annual average precipitation is obtained with 5\% accuracy at best (Groisman and Legates 1994). Szilagyi et al. (2011), applying the present ET-mapping technique in Hungary, which has similar climatic conditions as the NSH, obtained a $\sim 5 \%$ accuracy for the mean 
annual ET estimates over a very wide range of spatial scales (plot scale to the size of the country: $93,000 \mathrm{~km}^{2}$ ). The accuracy was shown to be about $5-10 \%$ in Nebraska (Szilagyi et al. 2011), based on comparison with multiyear eddy-covariance and energy-balance Bowen-ratio measurements. In the current analysis, a 5\% error in the precipitation (due to the relatively flat topography of the NSH and low contribution of snow toward the annual water balance), together with a $10 \%$ error in the ET variables is assumed, which, when occurring independently, may lead to a $15 \%$ error in the $P$ minus ET value. Considering that ET in the Sand Hills is between $85-90 \%$ of precipitation at most locations (see the following), the water-balance method leads to a $\pm 90-135 \%$ error in the resulting recharge estimate. (The plus/minus values in the following sections always denote the error bounds of the specified variable rather than the standard deviation of its spatially distributed values). It is important to note that this range of uncertainty is not unusual for recharge estimations including field-based estimates. Considering the cost-effectiveness and large spatial scale of the MODIS-based method, this level of uncertainty should be acceptable for many applications including regional hydrologic modeling.

\section{Spatial distribution of recharge rates}

Spatially distributed recharge rates are displayed in Figure 4 . The high ET areas in the western and northcentral part of the study area (Figure 3) and the accompanying large groundwater-discharge rates (negative recharge values) mostly correspond to shallow inter-dunal lakes, wetlands and wet meadows which are preva- lent mainly in these parts of the region (Figure 5). In the eastern and south-eastern parts of the NSH, in contrast, the sand dunes are flatter and precipitation is more abundant, resulting in overall higher recharge rates, as seen in Figure 4; for the same reason, most of the agricultural activity within the NSH is also concentrated here, typically in the form of irrigated crops, predominantly corn and soybean (Figure 6). With a steep eastto-west gradient in annual $P$ rates (Figure 2), recharge changes dramatically below these crops in the northeastern part of the NSH (Figure 4). While non-irrigated areas in the eastern flank of the region $(P=700 \mathrm{~mm} / \mathrm{yr})$ receive relatively high annual recharge rates of about $200 \pm 85 \mathrm{~mm}$, irrigated crops still maintain an annual recharge rate of around $100 \pm 95 \mathrm{~mm}$ here, a value which dramatically changes by moving north- and westward (to $P<600 \mathrm{~mm} / \mathrm{yr}$ ), to reach an annual discharge of about $80 \pm 83 \mathrm{~mm}$ (i.e., ET is larger than precipitation) below these irrigated crops, as precipitation declines.

It appears that an annual precipitation rate of about $600 \mathrm{~mm}$ is a critical value under the current climate conditions of the Sand Hills. When an area receives less than approximately $600 \mathrm{~mm} / \mathrm{yr}$ in precipitation, irrigation leads to mean annual ET rates in excess of mean annual precipitation. It is likely that irrigation may also lead to enhanced recharge rates under the irrigated crops; however, this enhanced recharge may be largely offset or even exceeded by the water pumped from underneath the crops (predominantly center pivots in Nebraska), resulting in a diminished, zero or negative, recharge rates (Figure 4). Of course, when the irrigation water is imported from another location to the given
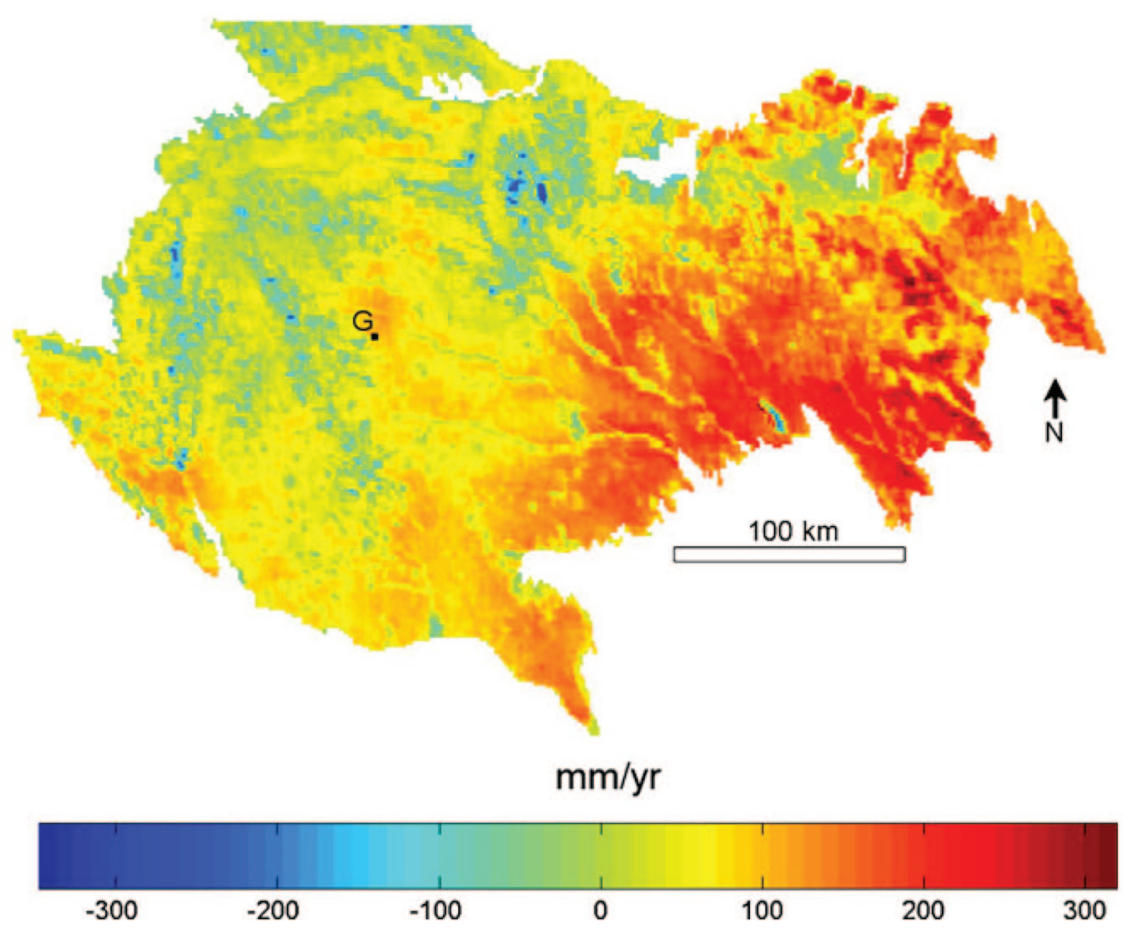

Figure 4. Mean annual recharge (mm) in the Sand Hills, estimated as the difference in period averaged (2000-2009) mean annual $P$ and EBBR-corrected ET rates. 


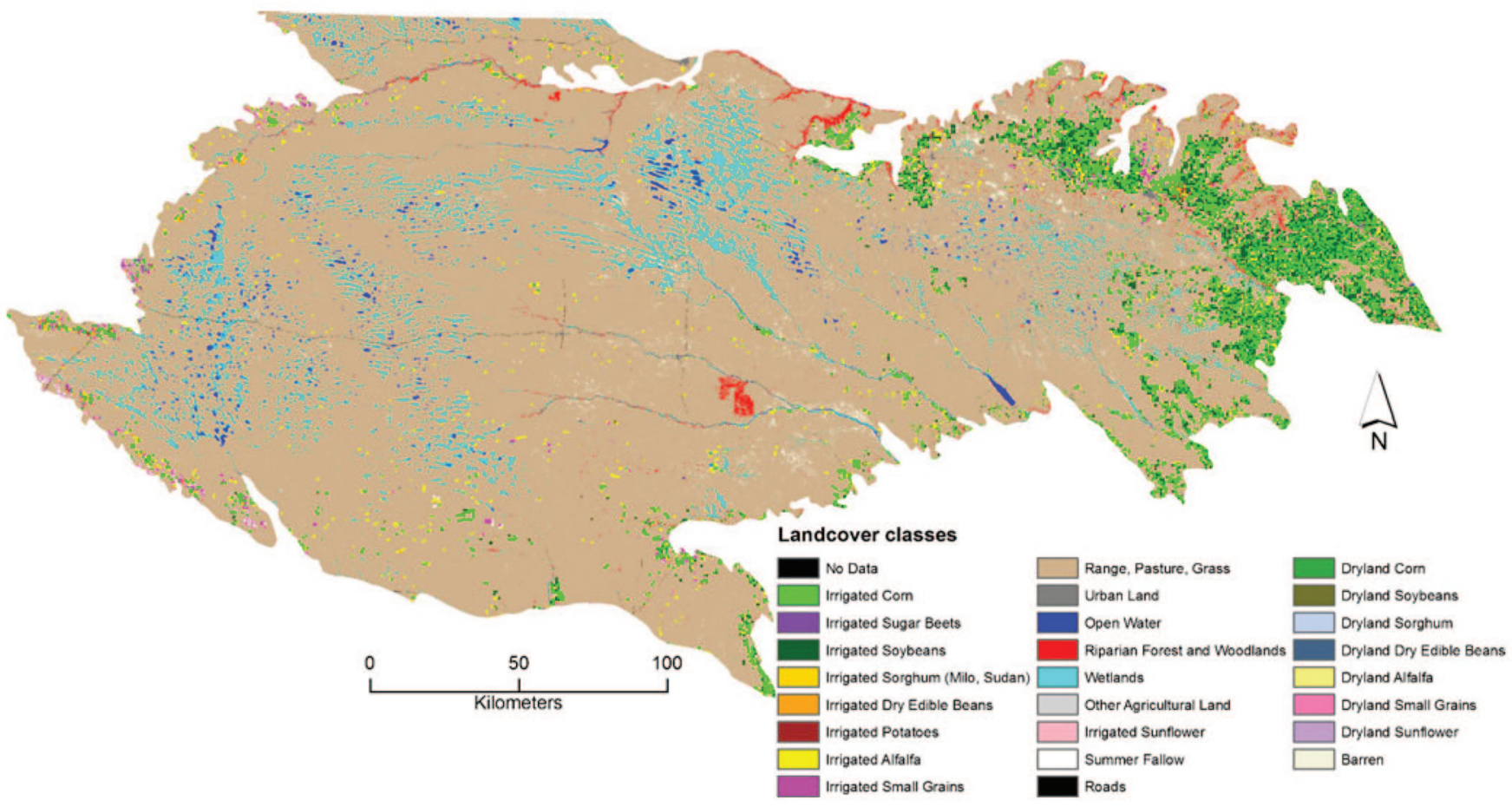

Figure 5. Land-use/land-cover distribution (after Dappen et al. 2007a) in the Sand Hills.

area (rare within the NSH), then no such offsetting can occur for the enhanced recharge values. Note also that as long as the irrigation water comes from the groundwater locally, recharge still can be correctly estimated as the difference in $P$ and ET, since the pumped water volume appears as inflow to the groundwater, added to $P$, but also appears as outflow, added to ET, thus cancelling each other in the $P$-ET term.

Also of interest is that some afforested areas seem to create groundwater discharge areas, most likely due to the greater depth to which tree roots can reach, potentially tapping into the capillary zone. The Halsey State Forest in the south-central part of the Sand Hills may be such a location (the largest red area near the center of Figure 5). Figures 4 and 7 predict that the forested land-mainly 50-70-year-old ponderosa pine (Pinus ponderosa) and eastern red cedar (Juniperus virginiana) in places may evaporate $5-10 \%$ more than it receives from precipitation.

The same has been reported in Hungary at the afforested (starting in the 1960s) locations in the inter-fluvial sand plateau region between the River Danube and its tributary, the Tisza River in the central part of the country. The region, with a climate similar to the Sand Hills', became a problem-area for water-resources managers, agriculturalists and ecologists due to the long-term groundwater decline (Szilagyi and Vorosmarty 1997) identified between 1970 and 1995. The MODIS-derived

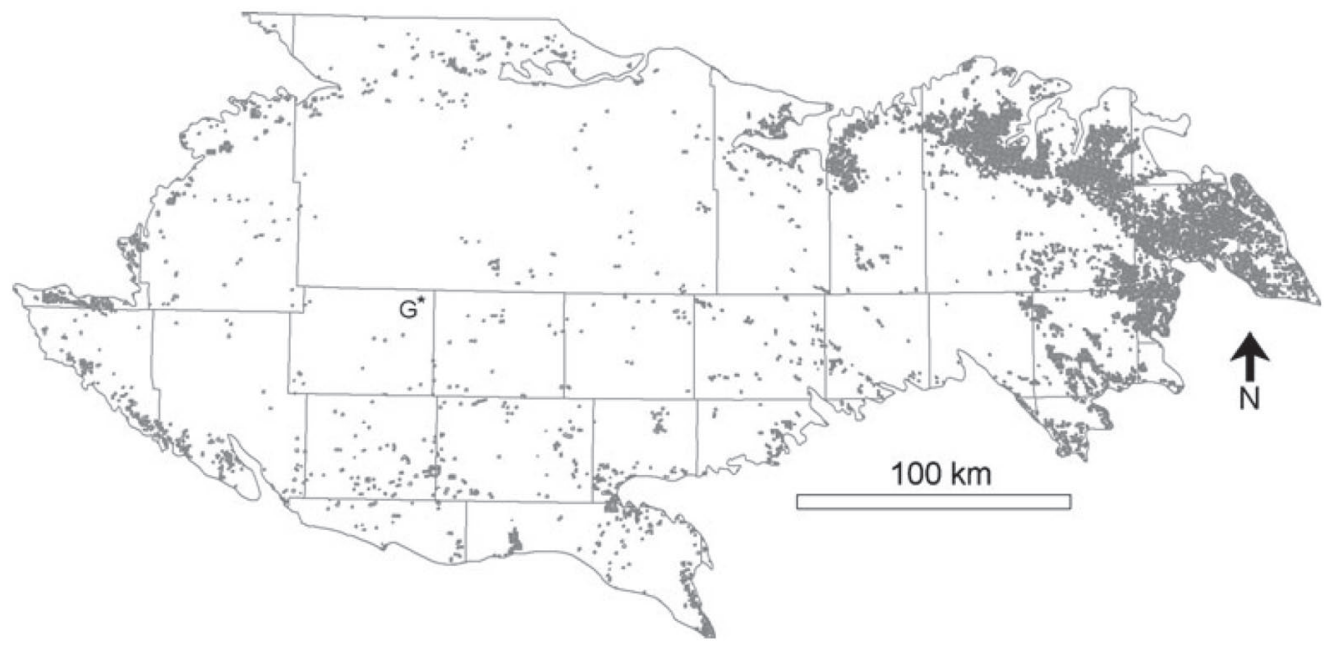

Figure 6. Distribution of center-pivot irrigation systems in the Sand Hills (after Dappen et al. 2007b) 


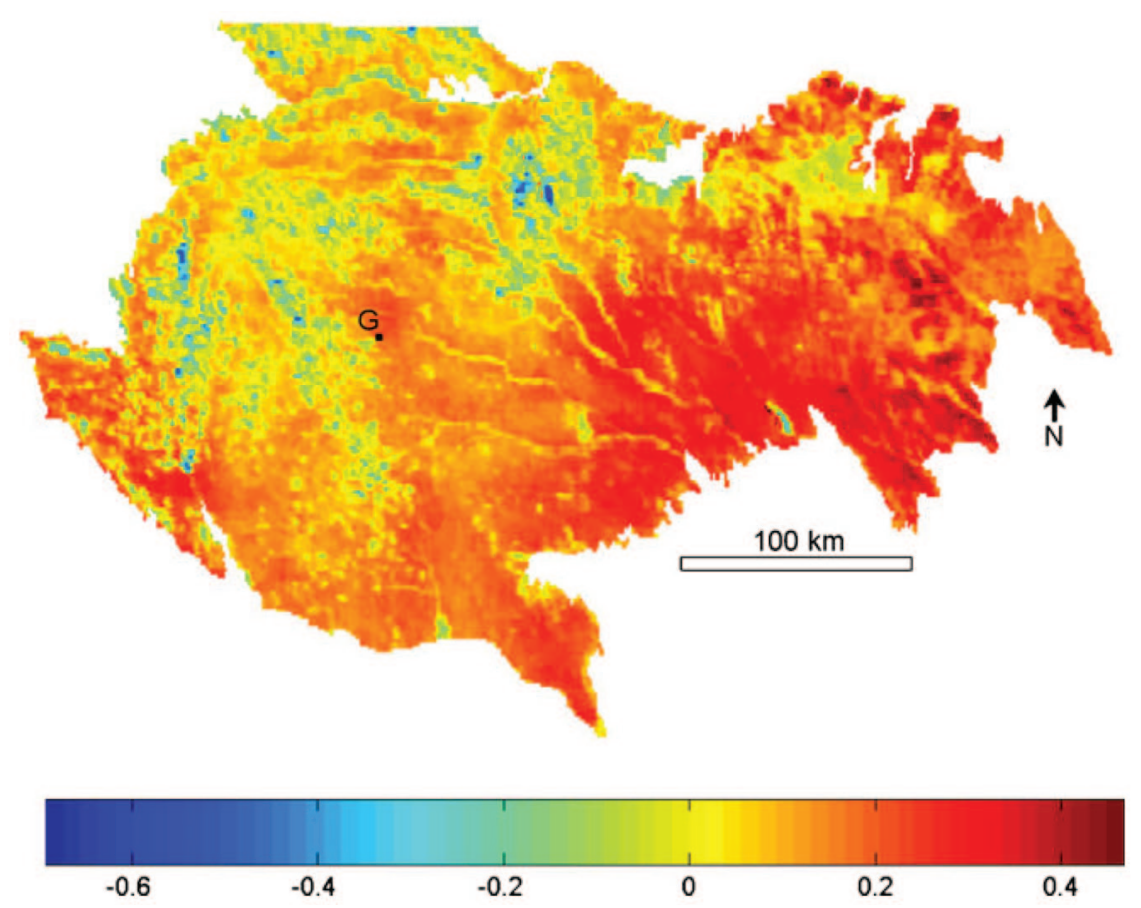

Figure 7. Mean annual recharge to precipitation ratio (-) in the Sand Hills.

ET map there also predicts that some afforested areas evaporate more than the precipitation rate they receive (Szilagyi et al. 2011). Having a groundwater ridge under the sand plateau, this is only possible if the forests create a depression in the water table, thus inducing local groundwater flow directed toward them which then supplies the difference in ET and precipitation. In fact, this has been reported by Major (1976, in Stelczer 2000) in Hungary who found that under a young forest in the region the water table was on average $1 \mathrm{~m}$ deeper than in the surrounding non-forested areas. He calculated a mean annual ET rate of $712 \mathrm{~mm}$ for an actively growing black spruce community covering an area of $500 \times 500 \mathrm{~m}$. On average, the forest consumed $130 \mathrm{~mm}$ more water annually than it received from precipitation. Mapped ET rates (Szilagyi et al. 2011) match these findings, yielding $620 \mathrm{~mm}$ annual ET for several forested locations in the area (this value may go up to $650 \mathrm{~mm}$ in certain pixels), which is about $80 \mathrm{~mm}$ more than the mean annual precipitation rate $(540 \mathrm{~mm})$ of the region. The elevated ET rates of these forests had earlier been pointed out by Szilagyi and Vorosmarty (1997) employing a complex regional, coupled surface-water/groundwater balance model. It is for future research (under planning) to verify whether the same indeed happens in the Sand Hills, as Figs. 4 and 7 predict, since generalized regional groundwater maps give a considerably larger depth to water $(>15 \mathrm{~m})$ in the NSH than the observed 2-10 $\mathrm{m}$ in Hungary (Szilagyi and Vorosmarty 1997). Also, an Australian-wide study found negligible groundwater use by vegetation when depth to groundwater exceeded $6 \mathrm{~m}$ (O'Grady et al. 2010).

Recharge is typically the smallest (about $40 \pm 59 \mathrm{~mm}$ or $10 \pm 14 \%$ of $P$ ) in the western part of the NSH, where annual precipitation is only about $420 \mathrm{~mm}$. The river valleys in general show up as low net recharge areas (the linear features in Figs. 4 and 7), because the water table is typically closer to the surface here than elsewhere, away from the valleys, enabling the vegetation to use additional water (Wang et al. 2007; Maxwell and Kollet 2008).

\section{Intercomparison of recharge estimates}

\section{Baseflow/streamflow analysis and groundwater flow modeling}

Employing streamflow measurements for baseflow separation with additional regional ET estimates plus ET estimates for small lakes and phreatophyte-vegetated areas, Szilagyi et al. $(2003,2005)$ derived a mean annual recharge rate of $48 \mathrm{~mm}$ (or about $9 \%$ of $P$ for 1961-1990) for the NSH. This estimate is 34\% lower than the current MODIS-based recharge rate of $73 \pm 73 \mathrm{~mm}$ (or about $14 \pm 14 \%$ of $P$, see Figure 7 ) obtained by spatial averaging of the pixel values over the study area. The main reason for the present estimate being higher (disregarding the difference in study periods) than the baseflow-based estimate is that Szilagyi et al. (2003, 2005) employed an uncorrected regional ET value-resulting from the same method that provides the basis for the present spatially distributed ET rates - because field measurements of ET within the Sand Hills were not yet available. The uncorrected regional ET value relied on a scattered climate-station grid for the required atmospheric variables where none of the climate stations fell within the NSH, except for precipitation gauges. Rather than employing only streamflow measurements with the corresponding drainage areas, Szilagyi et al. (2003, 2005) derived recharge as the difference between $P$ and ET for the following reasons: (1) published drain- 


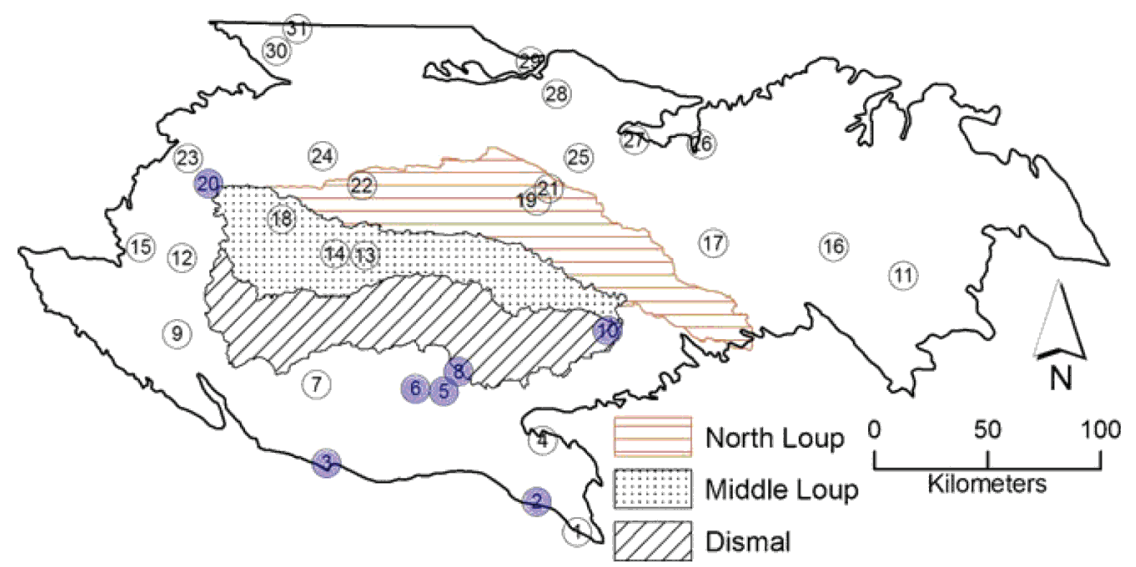

Figure 8. Watersheds within the Sand Hills employed for recharge comparison and the distribution of chloride mass balance data (circles) listed in Table 1. The darker circles denote locations with the most homogeneous land cover/land use. Location No. 13 is at the Gudmundsen ranch

age area values were found to vary by source; (2) in groundwater-dominated watersheds of a relatively flat terrain, the drainage area obtainable by a digital elevation model is of little relevance and may differ significantly from the drainage area derived from a groundwater elevation map; (3) groundwater elevation maps for extended areas are often generalized and thus not the best suited for drainage area delineations; (4) not all of the recharged water that escapes groundwater ET in the NSH will necessarily show up as streamflow within the region because some groundwater will leave the region via the regional groundwater flow system (mainly from west to east; Bleed and Flowerday 1989).

The present MODIS-based recharge rates, nonetheless, agree well (except for the Middle Loup River) with findings by Clover (1972) who used stream flowrate and drainage area values and by Chen and Chen (2004) who calibrated the recharge rates of their regional groundwater model to match observed groundwater elevations and stream flow-rates for watersheds

Table 1. Mean annual recharge rates, $R(\mathrm{~mm} / \mathrm{yr})$, in the NSH by chloride mass balance

\begin{tabular}{|c|c|c|c|}
\hline Site & Latitude (degrees) & Longitude (degrees) & $R$ \\
\hline 1 & 40.993 & -100.309 & 62 \\
\hline 2 & 41.113 & -100.524 & 50 \\
\hline 3 & 41.257 & -101.634 & 9 \\
\hline 5 & 41.55 & -101.019 & 108 \\
\hline 6 & 41.559 & -101.169 & 54 \\
\hline 7 & 41.569 & -101.695 & 78 \\
\hline 10 & 41.796 & -100.152 & 103 \\
\hline 11 & 42.002 & -98.572 & 45 \\
\hline 12 & 42.056 & -102.428 & 76 \\
\hline 13 & 42.082 & -101.45 & 74 \\
\hline 14 & 42.087 & -101.61 & 80 \\
\hline 15 & 42.093 & -102.649 & 32 \\
\hline 20 & 42.355 & -102.298 & 6 \\
\hline 21 & 42.357 & -100.467 & 72 \\
\hline 22 & 42.36 & -101.473 & 78 \\
\hline 23 & 42.454 & -102.41 & 123 \\
\hline 24 & 42.475 & -101.686 & 89 \\
\hline 25 & 42.481 & -100.305 & 79 \\
\hline 26 & 42.535 & -99.645 & 48 \\
\hline 27 & 42.551 & -100.009 & 60 \\
\hline 28 & 42.734 & -100.426 & 104 \\
\hline 29 & 42.864 & -100.572 & 127 \\
\hline 30 & 42.891 & -101.946 & 117 \\
\hline 31 & 42.982 & -101.836 & 55 \\
\hline Mean & & & 74 \\
\hline
\end{tabular}




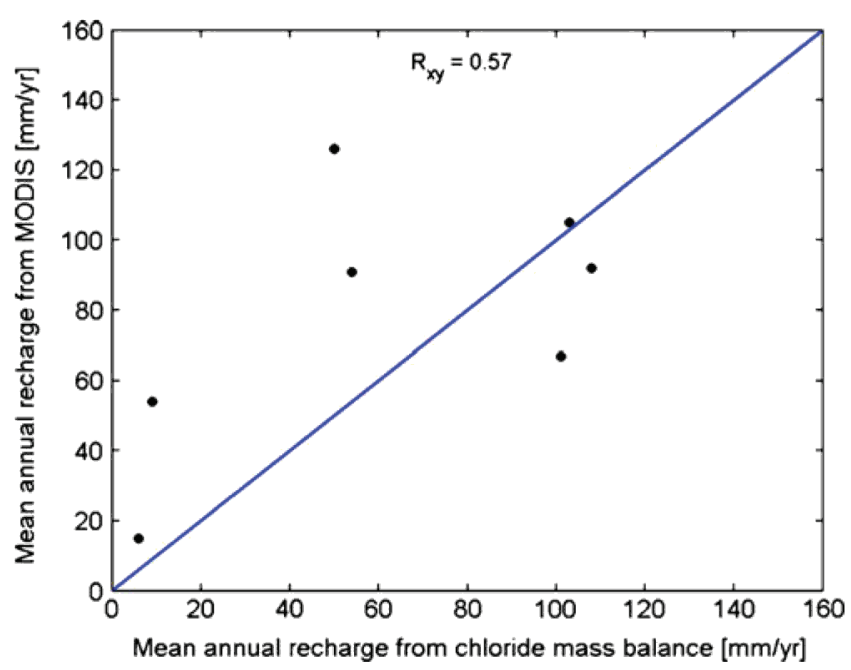

Figure 9. Regression plot of chloride mass balance and remotely sensed mean annual recharge rates for the seven most homogeneous locations. $R_{\mathrm{xy}}$ is the cross-correlation coefficient.

completely within the Sand Hills. Both Clover (1972) and Chen and Chen (2004) reported an estimated overall mean annual recharge rate of $13 \%$ of $P$ for the Middle Loup $(P=486 \mathrm{~mm} / \mathrm{yr})$ and Dismal Rivers $(P=506 \mathrm{~mm} /$ yr, Figure 8). Employing US Geological Survey published (http://water.usgs.gov) drainage areas and long-term stream discharge rates, and assuming that measured streamflow is predominantly baseflow, the corresponding recharge rates $(79$ and $56 \mathrm{~mm}$ ) become 16 and $11 \%$ of $P$, while the present estimates ( $43 \pm 69$ and $61 \pm 70 \mathrm{~mm}$ ) are $9 \pm 14 \%$ and $12 \pm 14 \%$ of $P$, respectively. For the North Loup River $(P=535 \mathrm{~mm} / \mathrm{yr})$, streamflow data yield a mean annual recharge rate of $71 \mathrm{~mm}$, or $13 \%$ of $P$, compared with a $75 \pm 73 \mathrm{~mm}$ value, or $14 \pm 14 \%$ of $P$ by the current method. The average mean annual recharge rate for the three adjacent watersheds (Figure 8 ) becomes $69 \mathrm{~mm}$, or $13 \%$ of $P(=506 \mathrm{~mm} / \mathrm{yr})$ from streamflow data versus the $65 \pm 69 \mathrm{~mm}$ value, or $13 \pm 14 \%$ of $P$ from the ET map.

\section{Cl-based estimation}

Chloride-based groundwater recharge estimates were performed at locations shown in Figure 8 (listed in Table 1). The arithmetic mean (equaling the spatially weighted mean employing an inverse distance method and rounded to the nearest integer) of these recharge estimates is $74 \mathrm{~mm} / \mathrm{yr}$ (almost identical to the MODIS-derived spatial average of $73 \mathrm{~mm} / \mathrm{yr}$ ) with a standard deviation of $33 \mathrm{~mm} / \mathrm{yr}$.

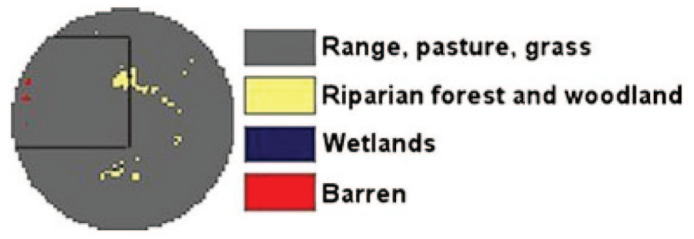

Figure 10. Land-cover distribution (after Dappen et al. 2007a) in a 1-km radius around site No. 2 in Table 1. The partial square denotes the MODIS cell that contains well No. 2.

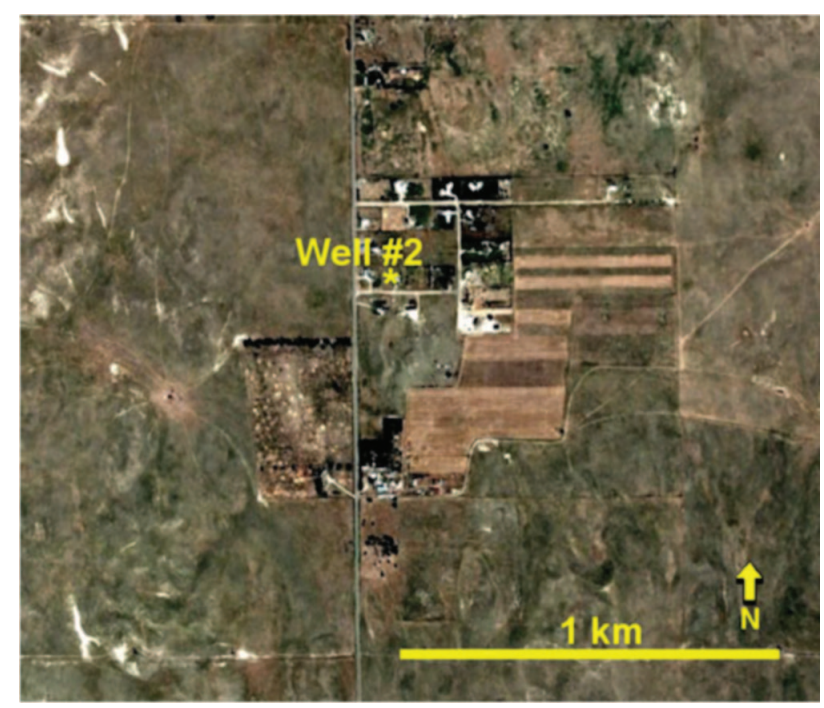

Figure 11. GoogleEarth image of the surroundings of well No. 2 where the largest difference in estimated recharge rates among the most homogeneous sites is found.

The assessment of spatial relationships between MODIS and chloride-based recharge estimates is hindered by differences in model assumption and area representations. In contrast to the MODIS recharge location (which is always the entire MODIS cell) the chloride mass balance location information (Table 1) represents the discharge location (e.g. well location) rather than the actual recharge location. In the absence of detailed information on groundwater flow paths, it is not possible

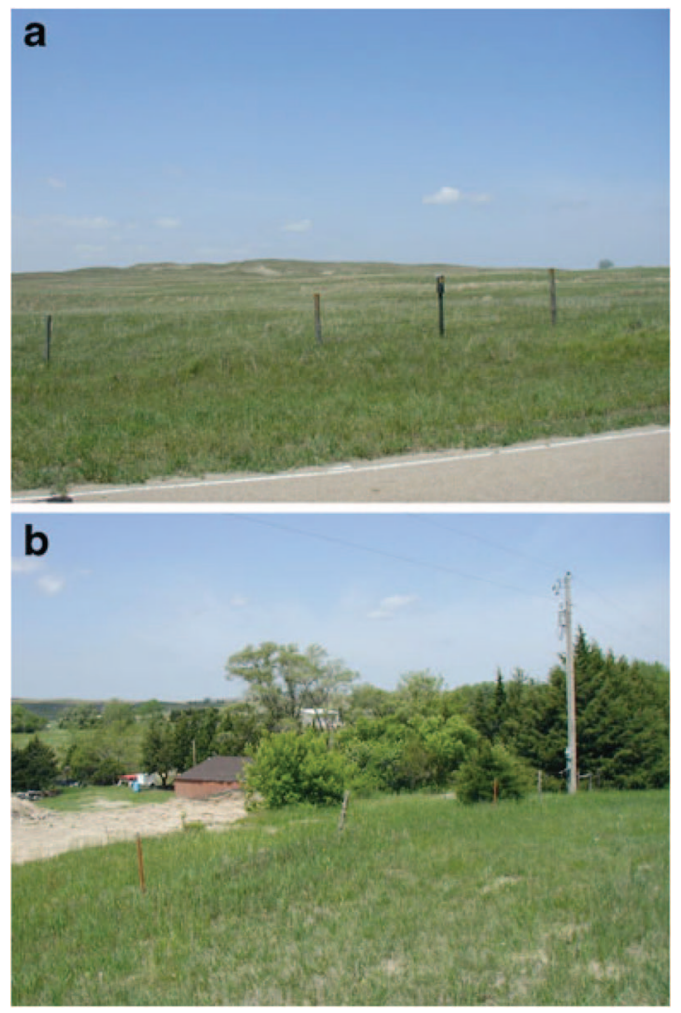

Figure 12. Land surface and vegetation around well No. 2. Looking at the (1) land within the MODIS cell in Figure 10, and; (2) immediate vicinity of the well. 
to attribute a given recharge rate estimate based on groundwater tracers to a particular recharge area. This is a common problem in tracer research requiring further groundwater flow modeling to address. Unsaturated zone chloride mass balance circumvents this complication because flow is often effectively one-dimensional, but sufficient unsaturated-zone chloride data is unavailable in this case. Also, in contrast to the MODIS-based recharge estimate, the chloride massbalance method does not account for groundwater discharge. Therefore in groundwater discharge areas it is possible to have a positive recharge rate estimate from chloride mass balance and a negative recharge rate estimate from the MODIS-based method. Another source for recharge-rate differences may come from inhomogeneity within the MODIS cell. If, for example, the well is located near a lake or an irrigated crop and the corresponding MODIS cell contains the lake/irrigated crop, the resulting MODIS-derived recharge rate may be depressed due to the high ET rates of the lake/irrigated crop, while the Cl-based estimate remains unaffected.

For these reasons, it is not surprising that the Cl-based recharge estimates from the locations in Table 1 do not correlate with the corresponding MODIS-cell ET rates. However, a further, more direct comparison between the two methods is attempted by utilizing land-use/landcover data (Dappen et al. 2007a) to select well locations with relatively homogeneous land cover/land use (indicated in darker circles in Figure 8). The selection was performed by defining a 1-km radius buffer zone around the well locations as the area within which a MODIS cell may still contain the well and the actual recharge zone of the well may most likely be found. Overlaying the land-use/ land-cover data with the buffer zones, the locations with the most homogeneous land cover/land use were selected by visual inspection of each well buffer zone.

A weak positive correlation between MODISbased and chloride-based recharge estimates is found $\left(R_{x y}=0.57\right)$ in this more homogeneous subset of the landscape (Figure 9). Across these sites, Cl-data yields a mean recharge rate of $62 \mathrm{~mm} / \mathrm{yr}$ with a standard deviation $(\sigma)$ of $44 \mathrm{~mm} / \mathrm{yr}$, while the MODIS-based method gives $79(\sigma=37) \mathrm{mm} / \mathrm{yr}$.

From Figure 9 it is obvious that there are still large differences in the two types of estimated recharge rates. Figure 10 displays the land-use/land-cover distribution (Dappen et al. 2007a) of the site (well No. 2 in Table 1 and the southern-most dark circle in Figure 8) with the largest difference in recharge rates (126 vs. $50 \mathrm{~mm} /$ yr). As seen, the dominant land-cover type is grass with smaller percentages of forests and wetlands. The distribution of land-cover types is similar inside the corresponding MODIS cell (the box in Figure 10), but without the presence of wetlands. More detailed imagery (from GoogleEarth in Figure 11, and field photographs in Figure 12a and b) indicates even stronger heterogeneity including buildings, large number of trees and crop fields. The larger-than-mean value of the MODIS-derived recharge estimate is most likely to be explained by (1) the above average precipitation rate of the site $(20 \mathrm{~mm} / \mathrm{yr}$ over the NSH mean), and; (2) flatter than average topography leading to the absence of inter-dunal lakes (Figure 5), which, due to their enhanced evaporations, depress the regional recharge rate. On the other hand, the lower-than-mean value of the $\mathrm{Cl}$-based estimate can be explained if the actual recharge area is close to the well location (the well is in a local depression of the land) where the tree and crop vegetation may result in locally low recharge rates. Alternatively, an anthropogenic $\mathrm{Cl}$ source (road salting in winter) in the vicinity (the well is close to an asphalt road, see Figure 11) would negatively bias -i.e., depress - the $\mathrm{Cl}$-based recharge estimate.

\section{Conclusions}

This study demonstrates the application of a waterbalance recharge estimation technique based on MODIS and ancillary climate data in the Nebraska Sand Hills region. Mean annual recharge rate estimates based on this method are consistent with independent estimates based on baseflow/streamflow, groundwater modeling and chloride mass balance (the latter over the most homogeneous well locations, with one exception; well No. 2 in Table 1) given their uncertainty ranges. The MODISbased method may be applicable for estimating spatially distributed mean annual recharge rates in sandy areas of the world where basic climate data (precipitation, air temperature and humidity, global radiation or sunshine duration) from the year 2000 and on (the temporal coverage of the MODIS data) are available. The advantages of the method is that it (1) provides spatially varying values without any kind of interpolation, thus the effect of land-use and/or vegetation-cover distribution to recharge rates becomes identifiable; (2) requires only typically easily accessible remotely sensed and standard climate data (without the need of any land-use or vegetation-related information), and; (3) is self-calibrating, thus eliminating the need for any (often cumbersome and site specific) parameter optimization. The uncertainty level of the resulting recharge-rate estimates can be easily defined from known or estimated levels of inaccuracy in the $P$ and ET variables. The associated error bounds in the recharge estimates may be significant in arid and semi-arid regions where a large portion of the precipitation is evaporated/transpirated. Such uncertainty is considered acceptable for many problems in view of the current state of uncertainty associated with other recharge estimation techniques.

Future efforts should be directed towards augmenting the currently available recharge estimates with multi-method point measurements (e.g., vadose-zone chloride mass balance) in this agriculturally important area of the High Plains, USA. Towards this goal, quantity and density of measurement points should be defined with consideration of environmental factors likely to affect recharge rates including topography, sediment structure, vegetation cover and climate. The spatial variability found in the recharge maps of the current study will allow for a better prioritization of the point-based measurement locations. 
Acknowledgements - This work has been supported by the Hungarian Scientific Research Fund (OTKA, No. 77364), the Agricultural Research Division of the University of Nebraska, and the National Science Foundation (ER-0609982SF). This work is connected to the scientific program of the "Development of quality-oriented and harmonized $\mathrm{R}+\mathrm{D}+\mathrm{I}$ strategy and functional model at BME" project. This project is supported by the New Szechenyi Plan (Project ID: TAMOP4.2.1/B-09/1/KMR-2010-0002). The authors would like to thank Dave Billesbach from UNL for the EBBR data in the Sand Hills. We also thank the Associate Editor and the three anonymous reviewers whose suggestions led to significant improvements of the original manuscript. The WREVAP FORTRAN code, with the corresponding documentation, can be downloaded from the personal website of JS (http://snr.unl. edu/szilagyi/szilagyi.htm).

\section{References}

Bleed A, Flowerday C (eds.) (1989) An atlas of the Sand Hills. Conservation and Survey Division, University of Nebraska, Lincoln, NE

Brunner P, Bauer P, Eugster M, Kinzelbach W (2004) Using remote sensing to regionalize local precipitation recharge rates obtained from the chloride method. J Hydrol 294(4):241-250

Brunner P, Hendricks-Franssen HJ, Kgotlhang L, Bauer-Gottwein P, Kinzelbach W (2007) How can remote sensing contribute in groundwater modeling? Hydrogeol J 15(1):5-18

Chen X, Chen X (2004) Simulating the effects of reduced precipitation on groundwater and streamflow in the Nebraska Sand Hills. J Water Resour Assoc 40(2):419-430

Clover RE (1972) Deep percolation in a Sand Hills area. J Water Resour Assoc 8(2):399-400

Crosbie RS, Jolly ID, Leaney FW, Petheram C (2010a) Can the dataset of field based recharge estimates in Australia be used to predict recharge in data-poor areas? Hydrol Earth System Sci 14:2023-2038. doi:10.5194/hess-14-2023-2010

Crosbie RS, McCallum JL, Walker GR, Chiew FHS (2010b) Modelling climate-change impacts on groundwater recharge in the Murray-Darling Basin, Australia. Hydrogeol J 18(7):1639-1656

Dappen P, Ratcliffe I, Robbins C, Merchant J (2007a) Map of 2005 land use of Nebraska. Center for Advanced Land Management Information Technologies, University of Nebraska, Lincoln, NE. http://www.calmit.unl. edu/2005landuse/statewide.shtml (October 12, 2010)

Dappen P, Ratcliffe I, Robbins C, Merchant J (2007b) Map of 2005 center pivots of Nebraska. Center for Advanced Land Management Information Technologies, University of Nebraska, Lincoln, NE. http://www.calmit.unl. edu/2005landuse/statewide.shtml (October 12, 2010)

Gates JB, Edmunds WM, Ma J, Scanlon BR (2008) Estimating groundwater recharge in a cold desert environment in northern China using chloride. Hydrogeol J 16:893-910

Groisman PY, Legates DR (1994) The accuracy of United States precipitation data. Bull Am Meteorol Soc 75:215-227

Healy RW (2010) Estimating groundwater recharge. Cambridge University Press, Cambridge

Korus J, Burbach M (2009) Groundwater-level changes in Nebraska, predevelopment to spring 2009. Conservation and Survey Division, Institute of Agricultural and Natural Re- sources, University of Nebraska, Lincoln, NB. http://snr. unl.edu/data/water/groundwatermaps.asp (October 12, 2010)

Major P (1976) Groundwater balance investigations in flat lands (in Hungarian). In: Piezometer readings, vol 2. VITUKI report, VITUKI, Budapest

Maxwell RM, Kollet SJ (2008) Interdependence of groundwater dynamics and land-energy feedbacks under climate change. Nature Geosci 1(10):665-669. doi:10.1038/ngeo315

National Oceanographic and Atmospheric Administration (NOAA) (2009) Surface radiation budget data. http:// www.atmos.umd.edu/ srb/gcip/cgi-bin/historic.cgi (June 25, 2011)

O'Grady A, Carter J, Holland K (2010) Review of Australian groundwater discharge studies of terrestrial systems. CSIRO: Water for a Healthy Country National Research Flagship, Adelaide, Australia, $60 \mathrm{pp}$

PRISM Climate Group(2004) Climate data. PRISM, Oregon State University, Portland, OR. http://prism.oregonstate. edu (June 25, 2011)

Scanlon BR, Goldsmith RS (1997) Field study of spatial variability in unsaturated flow beneath and adjacent to playas. Water Resour Res 33:2239-2252

Scanlon BR, Healy RW, Cook PG (2002) Choosing appropriate techniques for quantifying groundwater recharge. Hydrogeol J 10:18-39

State Agricultural Experimental Stations (SAES) (2010) National Atmospheric Deposition Program. http://nadp.sws. uiuc.edu (June 25, 2011)

Stelczer K (2000) Hydrological bases of water resources management (in Hungarian). ELTE Eotvos Kiado, Budapest, Hungary

Szilagyi J, Vorosmarty C (1997) Water-balance modeling in a changing environment: reductions in unconfined aquifer levels in the area between the Danube and Tisza rivers in Hungary. J Hydrol Hydromech 45:348-364

Szilagyi J, Harvey EF, Ayers J (2003) Regional estimation of base recharge to ground water using water balance and a base-flow index. Ground Water 41(4):504-513

Szilagyi J, Harvey FE, Ayers J (2005) Regional estimation of total recharge to ground water in Nebraska. Ground Water 43(1):63-69

Szilagyi J, Kovacs A, Jozsa J (2011) A calibration-free evapotranspiration mapping (CREMAP) technique. In Labedzki L (ed) Evapotranspiration. InTech, Rijeka, Croatia; http:// www.intechopen.com (June 25, 2011)

United States Geological Survey (USGS) (2009) National Water-Quality Assessment (NAWQA) Program. US Geological Survey, Reston, VA. http://water.usgs.gov/nawqa (June 25, 2011)

Wang T, Zlotnik VA, Wedin D, Wally KD (2007) Spatial trends in saturated hydraulic conductivity of vegetated dunes in the Nebraska Sand Hills: effects of depth and topography. J Hydrol 349:88-97. doi:10.1016/j.jhydrol.2007.10.027

Wang T, Zlotnik VA, Simunek J, Schaap M (2009) Using process-based models and pedotransfer functions for soil hydraulic characteristics to estimate groundwater recharge in semi-arid regions. Water Resour Res 45:W04412. doi:10.1029/2008WR006903

Yang X, Ma N, Dong J, Zhu B, Xu B, Ma Z, Liu J (2010) Recharge to the inter-dune lakes and Holocene climatic changes in the Badain Jaran Desert, western China. Quat Res 73:10-19 
Cartographie de la recharge annuelle moyenne de la nappe d'eau souterraine des Sand Hills, Nebraska, Etats-Unis

\section{Résumé}

La recharge annuelle moyenne dans les Sand Hills, Nebraska (Etats-Unis) a été estimée sur une période allant de 2000 à 2009, selon une résolution spatiale de $1 \mathrm{~km}$, en l'assimilant à la différence entre les moyennes annuelles des précipitations $(P)$ et de l'évapotranspiration (ET). Les valeurs mensuelles de $P$ provenaient de la banque de données PRISM, tandis que les valeurs mensuelles d'ET étaient tirées de la transformation linéaire des températures journalières au sol de MODIS en taux d'ET à l'échelle du pixel, en utilisant les métadonnées atmosphériques (température de l'air, humidité et radiation globale). L'aire d'étude reçoit une recharge annuelle de $73 \mathrm{~mm}$ environ (avec un intervalle d'erreur de $\pm 73 \mathrm{~mm}$ ), ce qui représente environ $14 \pm 14 \%$ des précipitations moyennes annuelles régionales, estimées à $533 \mathrm{~mm}$. Les valeurs de recharge les plus élevées (environ $200 \pm 85 \mathrm{~mm}$ ou $30 \pm 12 \%$ de $P$ ) se trouvent dans le secteur Sud-Est des Sand Hills, car les terrains sont moins accidentés et les précipitations plus abondantes $(700 \mathrm{~mm}$ environ) ; les valeurs les plus faibles (environ $40 \pm 59 \mathrm{~mm}$ ou $10 \pm 14 \%$ de $P$ ) sont observées dans le secteur Ouest, où les précipitations annuelles sont seulement de l'ordre de $420 \mathrm{~mm}$. Plusieurs éléments se comportent typiquement comme des zones de drainage pour les eaux souterraines : les lacs, les zones humides, les dépressions inter dunaires humides, les cours d'eau, les cultures irriguées (sauf dans le secteur Sud-Est) et certaines aires de reboisement dans le secteur Centre-Sud de la zone d'étude.

\section{Mapeo de la recarga anual media en Nebraska Sand Hills, EEUU}

\section{Resumen}

Se estima la recarga media anual en Sand Hills de Nebraska (EEUU) para el período 2000-2009 con una resolución espacial de 1-km como la diferencia de la precipitación media anual $(P)$ y la evapotranspiración (ET). Los valores mensuales de $P$ provienen del conjunto de datos PRISM, mientras que los valores mensuales de ET fueron derivados de transformaciones lineales de los valores de temperatura de la superficie terrestre de MODIS del día en pixeles de tasas de ET con la ayuda de datos atmosféricos auxiliares (temperatura del aire, humedad, y radiación global). El área de estudio recibe anualmente unos $73 \mathrm{~mm}$ de recarga (con un error límite de $\pm 73 \mathrm{~mm}$ ), que es aproximadamente $14 \pm 14 \%$ del valor de la precipitación anual media de $533 \mathrm{~mm}$. Las mayores tasas de recarga (aproximadamente $200 \pm 85 \mathrm{~mm}$ o $30 \pm 12 \%$ de $P$ ) ocurren la parte sudeste de Sand Hills debido al terreno suave y la más abundante precipitación (cerca de $700 \mathrm{~mm}$ ), mientras que la recarga es menor (aproximadamente $40 \pm 59 \mathrm{~mm}$ o $10 \pm 14 \%$ de $P$ ) en la parte oeste, donde la precipitación anual sólo es de unos $420 \mathrm{~mm}$. Típicamente, lagos, humedales, valles interdunales húmedos, ríos, cultivos irrigados (excepto en la región sudeste) y ciertas partes de las áreas no forestadas en la porción centro sur del área de estudio actúan como áreas de descarga de agua subterránea.
Mapeamento da recarga anual média das águas subterrâneas em Sand Hills, Nebraska, EUA

\section{Resumo}

Foi estimada a média da recarga anual, com uma resolução espacial de $1 \mathrm{~km}$, durante o período 2000-2009, em Sand Hills, no Nebraska (EUA), como resultado da diferença entre a precipitação média anual $(P)$ e a evapotranspiração (EVT). Os valores mensais de $\mathrm{P}$ foram obtidos da base de dados PRISM, enquanto os valores mensais de EVT foram derivados da base de dados MODIS com transformações lineares dos valores diários da temperatura da superfície terrestre em pixéis de taxas de EVT com recurso a dados atmosféricos auxiliares (temperatura do ar, humidade e radiação global). A área de estudo recebe anualmente cerca de $73 \mathrm{~mm}$ de recarga (com um limite de erro de $\pm 73 \mathrm{~mm}$ ), que é cerca de $14 \pm 14 \%$ do valor médio regional de $P(533 \mathrm{~mm})$. As maiores taxas de recarga (cerca de $200 \pm 85 \mathrm{~mm}$ ou $30 \pm 12 \%$ de $P$ ) ocorrem na parte sudeste de Sand Hills, devido à superfície topográfica mais suave e à ocorrência mais abundante de precipitação (cerca de $700 \mathrm{~mm}$ ), enquanto a recarga é menor (cerca de $40 \pm 59 \mathrm{~mm}$ ou $10 \pm 14 \%$ de $P$ ) na parte ocidental, onde a precipitação anual é de apenas cerca de $420 \mathrm{~mm}$. Regra geral, lagos, zonas húmidas, lagoas interdunares, rios, áreas de culturas regadas (excepto na região sudeste) e certas regiões de áreas florestadas na área centro-sul da zona de estudo funcionam como áreas de descarga de águas subterrâneas. 


\section{Mapping mean annual groundwater recharge in the Nebraska Sand Hills, USA}

Jozsef Szilagyi, Vitaly A. Zlotnik, John B. Gates, Janos Jozsa

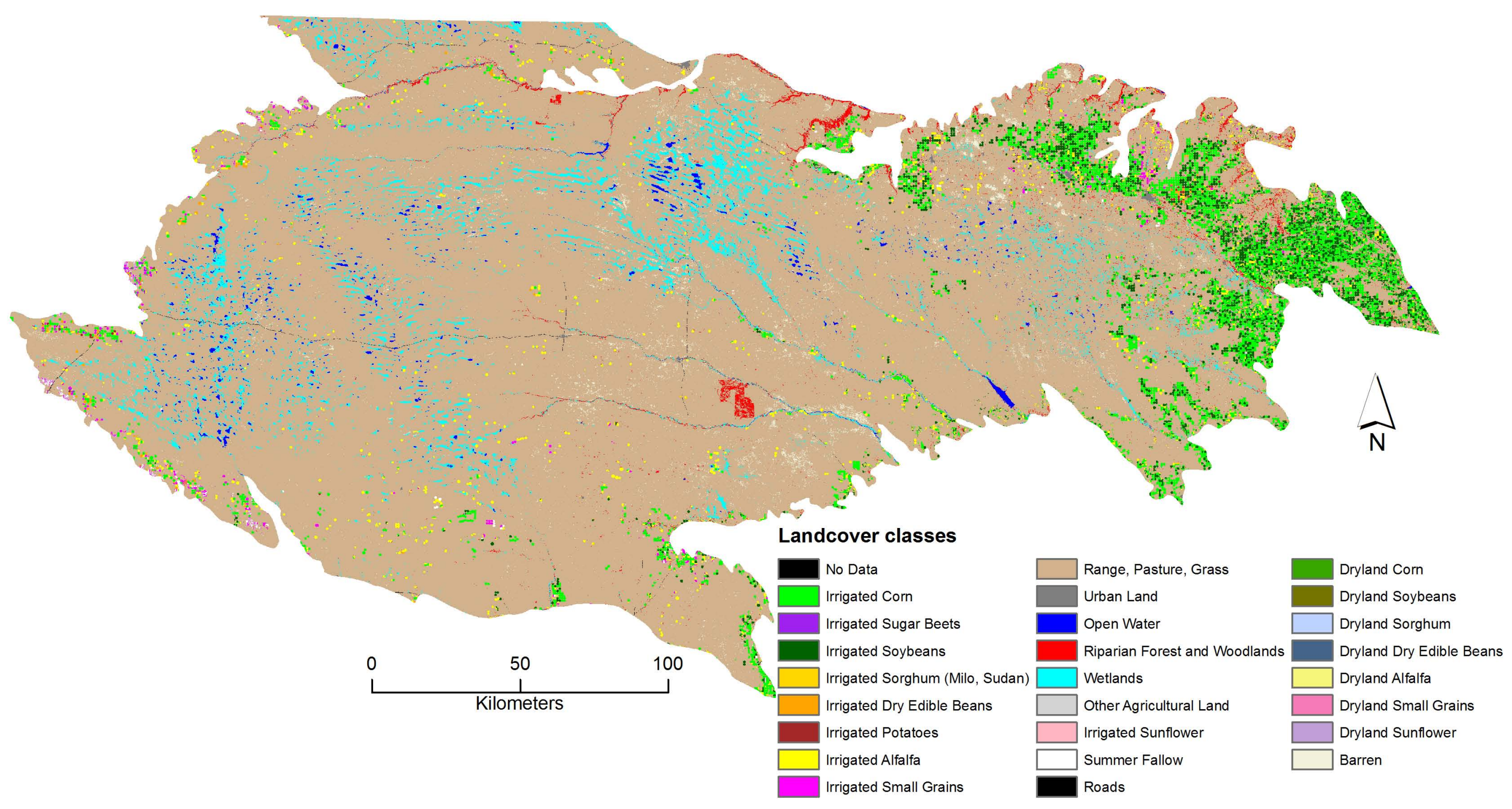

Figure ESM1: Copy of Fig 5 of the main article - Land-use/land-cover distribution (after Dappen et al. 2007a) in the Sand Hills 